\title{
Digital cervicography and cold coagulation for cervical cancer screening in Nigeria
}

\author{
Clement Adebamowo ${ }^{1,2^{*}}$, Maryam Almujtaba' ${ }^{1}$, Zahra Modibbo ${ }^{1}$, Olayinka Olaniyan ${ }^{3}$ William Blattner ${ }^{1}$ \\ From 13th International Conference on Malignancies in AIDS and Other Acquired Immunodeficiencies \\ (ICMAOI) \\ Bethesda, MD, USA. 7-8 November 2011
}

\section{Background}

Cervical cancer (CC) is most common cancer among women in Africa and in women living with $\operatorname{HIV}[1,2]$. Its prevalence has remained stable or increasing with introduction of HAART suggesting complex interactions with HIV $[3,4]$. Current screening programs can substantially reduce all-cause mortality of CC but implementation in LMIC is hobbled by poor infrastructure, cost and lack of personnel. Nurse provider led, minimal visit, screen and treat programs offer an opportunity to reduce $\mathrm{CC}$ morbidity and mortality in LMIC [5]. In this study we evaluate the implementation of cervical cancer screen and treat programs at 2 HIV treatment and prevention sites in Nigeria.

\section{Material and methods}

CC screening programs using nurse providers, VIA, off the shelf camera for digital cervicography, treatment of eligible lesions by cold coagulation and referral as required was implemented at 2 PEPFAR supported sites in Abuja, Central Nigeria. QA was provided by Gynecologist and based on weekly review of digital cervicographs and client recall as required.

\section{Results}

From July 2010 to July 2011, 2002 HIV+ women had been screened for CC at the 2 sites, but only data on 925 is reported in this abstract. Mean (SD) age was 35.2 (7.0) years; mean (sd) age at sexual debut was 19.0 (3.9) years; range, mean, sd of pregnancies was $0-16,3.4$, 2.5; range, mean, sd of pregnancies was $0-12,1.6,1.8$;

\footnotetext{
* Correspondence: cadebamo@yahoo.com

'Office of Strategic Information, Research and Training, Institute of Human Virology, Abuja, Nigeria

Full list of author information is available at the end of the article
}

range, mean, sd of most recent cd4 count before screening was 11 - 1197, 466.7, 239.0; 6.8\% were VIA positive; $0.2 \%$ had invasive CC and $0.2 \%$ were uncertain. Concordance between the clinical review and nursing diagnosis was $65 \%$ at the beginning of the program but reached $100 \%$ after 3 months.

\section{Conclusions}

This study showed nurse provider led CC screening and treatment program is a viable public health intervention among PLWHIV in Nigeria.

\section{Acknowledgement}

This study is supported by the IHV-UM Capacity Development for Research into AIDS Associated Malignancies (NIH/NCI D43CA153792-01 PI, Adebamowo) and IHV-UM AIDS International Training and Research Program (NIH/FIC D43TW001041-11 Pl, Blattner).

\section{Author details}

${ }^{1}$ Office of Strategic Information, Research and Training, Institute of Human Virology, Abuja, Nigeria. ${ }^{2}$ Department of Epidemiology, Institute of Human Virology, University of Maryland School of Medicine, Baltimore, MD, USA. ${ }^{3}$ National Hospital, Abuja, Nigeria.

\section{Published: 19 April 2012}

\section{References}

1. Boyle P, Levin B: World Cancer Report 2008 Geneva: International Agency for Research on Cancer; 2008.

2. Clarke B, Chetty R: Postmodern cancer: the role of human immunodeficiency virus in uterine cervical cancer. Mol Pathol 2002, 55:19-24.

3. Mbulaiteye SM, Katabira ET, Wabinga H, Parkin DM, Virgo P, Ochai R, Workneh M, Coutinho A, Engels EA: Spectrum of cancers among HIVinfected persons in Africa: the Uganda AIDS-Cancer Registry Match Study. Int J Cancer 2006, 118:985-990.

4. Schiffman M, Castle PE, Jeronimo J, Rodriguez AC, Wacholder S: Human papillomavirus and cervical cancer. Lancet 2007, 370:890-907.

\section{Biomed Central}

(c) 2012 Adebamowo et al; licensee BioMed Central Ltd. This is an open access article distributed under the terms of the Creative Commons Attribution License (http://creativecommons.org/licenses/by/2.0), which permits unrestricted use, distribution, and reproduction in any medium, provided the original work is properly cited. 
5. Mwanahamuntu MH, Sahasrabuddhe W, Kapambwe S, Pfaendler KS,

Chibwesha C, Mkumba G, Mudenda V, Hicks ML, Vermund SH, Stringer JS,

Parham GP: Advancing cervical cancer prevention initiatives in resourceconstrained settings: insights from the Cervical Cancer Prevention Program in Zambia. PLoS Med 2011, 8:e1001032.

doi:10.1186/1750-9378-7-S1-P14

Cite this article as: Adebamowo et al: Digital cervicography and cold coagulation for cervical cancer screening in Nigeria. Infectious Agents and Cancer 2012 7(Suppl 1):P14.

Submit your next manuscript to BioMed Central and take full advantage of:

- Convenient online submission

- Thorough peer review

- No space constraints or color figure charges

- Immediate publication on acceptance

- Inclusion in PubMed, CAS, Scopus and Google Scholar

- Research which is freely available for redistribution

Submit your manuscript at www.biomedcentral.com/submit
() Biomed Central 